\section{Horse sickness and ENSO in South Africa}

African horse sickness (AHS) is the most lethal infectious horse disease, with mortality rates in susceptible animals of up to $95 \%$ (ref. 1). Since its discovery at Cape Colony in the early eighteenth century, major epizootics of this viral disease have occurred in South Africa once every 10 to 15 years on average; in the largest epizootic, more than $40 \%$ of the entire horse population died. However, the cause of these major epizootics has remained unknown until now. We have found a very strong association between the timing of these epizootics and the warm (El Niño) phase of the El Niño/Southern Oscillation (ENSO), and suggest that the association is mediated by the combination of rainfall and drought brought to South Africa by ENSO.

AHS is endemic to sub-Saharan Africa but epizootics are particularly frequent and severe in South Africa, which has a large population of susceptible horses, many zebra (the vertebrate reservoir of the AHS virus) and a widespread distribution of its principal insect vector, the biting midge Culicoides imicola. This vector and closely related species are widespread in the Old World. AHS outbreaks have occurred in Europe and Asia, with up to 300,000 equids dying in a single epizootic. Both North America and Australia, which have competent vectors, are also at risk.

ENSO, a periodic ocean-atmosphere fluctuation in the Pacific Ocean, is a major cause of climatic variability over much of the world, including southern Africa ${ }^{2}$. ENSO events have been correlated with epidemics of several mosquito-borne diseases $^{3-6}$ in parts of the world where ENSO teleconnections are strongest (the Pacific, South America and south Asia), although the associations themselves are not very strong and most data sets have been relatively short. In South Africa, the high value of horses and their extreme mortality rate from AHS means that good records were kept of AHS epizootics, allowing us to investigate historical patterns of the disease.

Since 1803, from which time there have been sufficient data to reconstruct El Niño events of at least moderate strength ${ }^{7}$, there have been 14 large epizootics of AHS in South Africa $(1819,1837$ or $1839,1854-55$, 1862-63, 1877-78, 1887-88, 1891-92, 1913-14, 1918, 1923, 1925, 1940, 1953 and 1996). A list of 55 warm-phase ENSO events $^{8,9}$ between 1803 and 1997 includes the following (part years omitted): 1819, 1837-39, 1854-55, 1862, 1877-78, 1888, 1891, 1914, 1918-19, 1923, 1925-26, 1940 and 1953. Of the 14 AHS epizootics, only the most recent (1996) did not coincide with a warm-phase ENSO. We calculate the probability of an epizootic coinciding with an ENSO by chance to be 0.554 if ENSO events last two years. On this basis, we conservatively estimate the probability of our finding (13 of 14 epizootics coincided with ENSO) is at most 0.0032 .

Warm-phase ENSOs bring both rainfall and drought to southern Africa ${ }^{10}$. Populations of the AHS virus vector, C. imicola, breed in damp soil and can increase 200fold in years of heavy rain, raising the possibility that ENSO-brought rain may cause the association with major AHS epizootics. However, heavy rainfall occurs for other reasons in many non-ENSO years but epizootics do not result.

We investigated climatic patterns for the western region of South Africa, where most of the major AHS epizootics have occurred. We obtained monthly rainfall data (since records began in 1842) from the South Africa Weather Bureau and calculated the average rainfall in each three-month period
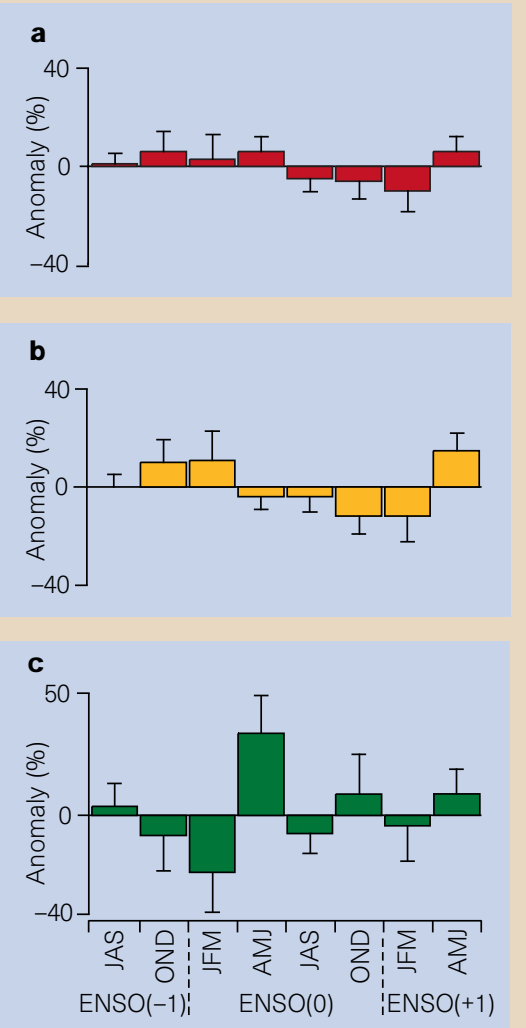

Figure 1 Average rainfall anomalies in western South Africa. $\mathbf{a}$, Years of ENSO; $\mathbf{b}$, years of ENSO without AHS epizootics; $\mathbf{c}$, years of ENSO with AHS epizootics. The number of years averaged are 43 , 32 and 11, respectively. Zero represents the average rainfall experienced in 113 non-ENSO years. Bars show percentage deviation (+s.e.) from this average for three-monthly intervals (JAS, July to September; OND, October to December; JPM, January to March; AMJ, April to June) over a two-year period. Data are means of rainfall anomalies at Cape Town Royal Observatory and Worcester. of the year. From these values, we estimated the rainfall anomaly (the percentage deviation from the mean rainfall in non-ENSO years) over the potential two-year time course of a warm-phase ENSO, from six months before the ENSO year to six months after it.

Warm-phase ENSOs typically have heavy rain followed by drought (Fig. 1a). Similar patterns are apparent in those warm-phase ENSO years when there was no epizootic of AHS (Fig. 1b). However, the average rainfall patterns are different in the warm-phase ENSO years when there were also epizootics of AHS (Fig. 1c). There is pronounced drought in the early part of the ENSO year, followed by heavier rain than usual between April and June. Heavy rainfall and drought are not limited to warmphase ENSO events but the combination is favoured by them. Only 4 per cent of nonENSO years combined drought from January to March and heavy rain from April to June, compared with nearly $20 \%$ of ENSO years $\left(\chi^{2}, P<0.01\right)$.

But how does a spell of drought followed by heavy rainfall affect AHS epizootics? Breeding sites of the insect vector may be altered or, during drought, the virus reservoir (zebra) may congregate near the few remaining sources of water where they are in contact with, and infect, more vectors. High temperature during droughts increases vector population growth rates and favours virus transmission. Although the reasons are not known, the significance of drought to AHS in South Africa has been long appreciated. In 1863, before the causative agent of the disease and its vector were known, or effects of ENSO on southern Africa were suspected, it was observed that "there are seasons (usually wet ones) succeeding drought, in which great mortality occurs among horses at the fall of the year"

Matthew Baylis ${ }^{\star}$, Philip S. Mellor ${ }^{\star}$,

Rudy Meiswinkel $\dagger$

${ }^{*}$ Institute for Animal Health,

Ash Road, Pirbright, Surrey GU24 ONF, UK

e-mail:matthew.baylis@bbsrc.ac.uk

$\dagger$ Onderstepoort Veterinary Institute,

Onderstepoort 0110, South Africa

$\$$ Present address: Institute for Animal Health,

Compton, Newbury, Berkshire RG20 7NN, UK

1. Hess, W. R. in The Arboviruses: Epidemiology and Ecology (ed. Monath, T.P.) 1-18 (CRC Press, Boca Raton, Florida, 1988).

2. Nicholson, S. E. \& Kim, J. Int. J. Climatol. 17, 117-135 (1997).

3. Nicholls, N. Lancet 342, 1284-1285 (1993).

4. Bouma, M. J. \& van der Kaay, H. J. Trop. Med. Int. Health 1, 86-96 (1996).

5. Bouma, M. J. et al. Trop. Med. Int. Health 2, 1122-1127 (1997).

6. Hales, S., Weinstein, P. \& Woodward, A. Lancet 348, 1664-1665 (1996).

7. Quinn, W. H., Neal, V. T. \& de Mayolo, S. E. A. J. Geophys. Res. 92, 14449-14461 (1987).

8. Quinn, W. H. in El Niño. Historical and Paleoclimatic Aspects of the Southern Oscillation (eds Diaz, H. F. \& Markgraf, V.) 119-149 (Cambridge Univ. Press, 1992).

9. Webster, P. J. \& Palmer, T. N. Nature 390, 562-564 (1997).

10. Ropelewski, C. F. \& Halpert, M. S. Mon. Weath. Rev. 115, 1606-1626 (1987).

11. Paton, T. Veterinarian 36, 489-494 (1863). 